\title{
Towards systemic change: on the co-creation and evaluation of a study programme in transformative sustainability science with stakeholders in Luxembourg
} Ariane König

\begin{abstract}
This paper examines a study programme in 'Sustainability and social innovation' at the University of Luxembourg that was cocreated with key external stakeholders in local sustainability transitions. The programme's aim is to equip scientists and citizens for the practice of transformative sustainability science to change human environment interactions. Addressing socially salient, complex problems invites a re-conception of what role universities can play in knowledge production processes in more applied and local contexts. We critically discuss the programme's ambition to provide a platform for transformative social learning for sustainability and to contribute to fostering systemic change in Luxembourg. We deduce design requisites to achieve these ambitions. The paper also discusses the role of different forms of evaluation in effecting individual, programme and systemic change.

Research insights were drawn from documentary and literature research, concept-building, programme implementation, observation, analysis, and evaluation by students and contributors.
\end{abstract}

\section{Address \\ University of Luxembourg \\ Corresponding author: König, Ariane (ariane.koenig@uni.lu)}

\author{
Current Opinion in Environmental Sustainability 2015, 16:89-98 \\ This review comes from a themed issue on Sustainability science \\ Edited by Ariane König and Nancy Budwig \\ Received 16 May 2015; Revised 05 August 2015; Accepted 06 August \\ 2015 \\ http://dx.doi.org/10.1016/j.cosust.2015.08.006 \\ 1877-3435/C 2015 Elsevier B.V. All rights reserved.
}

\section{Introduction}

The persistent lack of action in response to growing evidence that our industrial metabolism exceeds the planet's biophysical carrying capacity and thereby threatens our life support system is causing increasing concern across the globe. The existential problems of civilization in the 21 st century are complex, as they involve interactions between society and culture, the techno-sphere and the environment. Traditional disciplinary fields of 'normal' science can only play a limited role in resolving such complex problems [1], especially considering the prevailing rift between the natural and the social sciences [2,3]. For these 'postnormal' problems society requires more diverse spaces for knowledge creation [4,5].

'Sustainability science' has been conceived as a new branch of science that is to take account of complexity and uncertainty by adopting a systems perspective [6]. Monitoring and learning are key goals of such research. Increasingly sophisticated conceptions of transformative sustainability science for fundamentally changing human-environment interaction are being designed and put into practice $\left[7-9,10^{\circ}, 11\right]$. The appropriate sciences for sustainability will involve recognition of complexity, conflict, uncertainty and ignorance. It can be argued that key to such transformative scientific inquiry is rethinking how new actionable knowledge is co-created in collaborative processes. With their combined mission of research, teaching and engagement, universities can play a leading role in establishing such processes.

This paper describes a study programme co-created at the University of Luxembourg, the Certificate in 'Sustainability and Social Innovation' (henceforth 'The Certificate') that was designed to equip research scientists, students and citizens for the practice of transformative sustainability science and to contribute to systemic change in Luxembourg over the long-term. The programme's creation was motivated by years of struggle in a scientific controversy on appropriate technologies for addressing challenges at the food-water-energy-health nexus (cf [12]). One aim was to develop a knowledge production process in Luxembourg that takes into account how science, technology, knowledge and social norms, values and practice are actually co-produced interdependently $\left[13^{\bullet \bullet}, 5,14\right]$. The content and approach of this study programme has been co-created with diverse groups of contributors and course participants from four continents, drawing on a wide range of disciplinary perspectives and experience from academia and practice. The programme is unique in the degree of diversity of its participants as it is open to students from any level or study programme and professionals, including from government, non-governmental organisations and the private sector. We consider this diversity essential to success. 
Research that guided the co-creation process and is the basis for this paper includes documentary and literature research in environmental and sustainability education, philosophy and sociology of science, as well as participant-observation and evaluation in individual reports and focus group meetings. These were the basis for conceptbuilding, implementation and subsequent observation, analysis and reflections, leading into further conceptbuilding, action and reflection cycles.

\section{Sustainability at the University of Luxembourg}

The University of Luxembourg (UL) is Luxembourg's first and only University. The unique attributes of Luxembourg and of the university that played a role in shaping of this study programme are listed in Box 1. Luxembourg is a small country with short paths to high-level decision-makers and politicians. In general terms, programme contributors have noted that the young university is proving remarkably flexible in accommodating innovative forms of education and research compared with a mature, large university, as for example the neighbouring University of Trier.

Another helpful facet is that inter-disciplinarity features as a key organizing principle in the 2003 law founding the university. However, securing external funding for programmes and projects that explicitly state the ambition of questioning prevailing social norms and structures in view of sustainability challenges seems to be at least as difficult in Luxembourg that has a very traditional culture with a prominent saying 'mir wolle bleiwen wat mir sin' (we'd like to stay who we are), as elsewhere. The ability to draw on the University's own internal funds by establishing a Cell for Sustainability and endorsement of transdisciplinary activities bridging diverse disciplines and practice, also based on the legal remit, from the rector was a requisite for success.

The building the transdisciplinary activities on sustainability at the UL, including the Certificate would not have been possible without engagement in an international network of leading universities as the International Sustainable Campus Network (ISCN). The Head of Sustainability developed the UL's first Strategic Action Plan on Sustainability (2010-2013). ${ }^{1}$ in a participatory process with staff, students and external stakeholders at the same time as acting as lead-author for the ISCN Charter. After 21 of the world's leading Universities signed the Charter the UL President followed suit. The action plan's main goal is 'to engage students, staff and interested civil society in experiential learning about how to reduce environmental impacts and enhance social cohesion and build capacity to develop and implement solutions by drawing on different disciplines.' Work in international networks continues to inform local activities.

\footnotetext{
${ }^{1}$ www.uni.lu/sustainability.
}

Box 1 Unique attributes of the contextual and transactional environment of the University of Luxembourg (UL) shaping possibilities to build Sustainability Science and education for it

Luxembourg

- Luxembourg is a seat of major EU institutions (Part of EU Parliament and Commission, EUROSTAT, Court of Auditors, European Court of Justice) - the international community presents a pool of highly professional cross-culturally sensitive contributors and participants.

- The small size of Luxembourg and its government present short paths to decision-makers.

- Luxembourg's constitution prescribes that educational content has to be programmed by law.

The University of Luxembourg

- Created by law in 2003 as Luxembourg's first and only university

- A research oriented university with 3 faculties offering 46 Bologna study programmes at the Bachelor and Masters level in natural science, social science and humanities, law and economics and finance. Connection of research and teaching is a stated priority

- Article 3 . in the founding law prescribes inter-disciplinarity as a main organizing principle.

- International: Obligatory semester abroad for all Bachelors, trilingual (study programmes and administration in English, German and French), staff and students from over 100 different countries, under $50 \%$ Luxembourg students.

- Small: Seeking to cap at 7000 students to remain personable

- Sustainability is endorsed at the highest level: the president signed the International Sustainable Campus Network Charter 2010 (UL Head of Sustainability was lead-author of the Charter and plays a leading role in this network)

Network-building at the national, regional and international level allowed gaining visibility and recruiting an internationally and locally strong, loyal and influential team of contributors for the Certificate. It also benefits from a strong pool of professional mid-career participants from the EU institutions. The tri-lingual University has an international student body offering global perspectives.

Whilst different language abilities of contributors and participants remain a challenge, the advantages of strong international contributions and transferring knowledge from leading universities in this field elsewhere are considered to weigh out disadvantages. The main draw-back is that teaching in English reduces the potential to have traction with the local community. Improved ways to organize knowledge transfer to local networks seeking systemic change in Luxembourg is a key area for future improvements.

\section{The certificate in sustainability and social innovation}

The Certificate, approved as an official study programme in November 2012, is the university's first part-time programme open to Bachelor-, Master-, Ph.D.-students and professionals. The offering of the first course took 18 months to prepare employing an interdisciplinary team 
of ten natural and social scientists and two practitioners, which has been running since March 2011. After two further courses were built and experimentation with peer group projects had matured over two years, the package was presented and approved as a study programme. The programme's main stated goal is to serve as a platform for societal debate, social learning and network development to foster systemic transformation for sustainability in Luxembourg.

\section{How is 'learning' conceived of and who learns?}

The Certificate is conceived as a platform for a transformative social learning process; the main goal is to prompt scientific inquiry in diverse groups of stakeholders and experts. The underlying conception of social learning is similar to that described in Bart $\left[15^{\circ}\right]$ and Wals et al. $\left[10^{\circ}\right]$. It focuses on the relation of learning across different scales of social organization-individual, group, organizational or societal - and builds on prevailing conceptions of social learning in environmental management $[16,17])$. The conception of transformative learning as collective scientific inquiry is close to that described by Wals et al. $\left[10^{\circ}\right]$ and is rooted in John Dewey's work (1938) [18] and more recent interpretations of it [19]. Accordingly learning is a process of developing an enriched understanding and repertoire of action on problems as a result of open experimentation and judgment of results following criteria of rationality. The fact of knowing more and mastering knowledge in a different manner changes our relationship between the world and ourselves. Progress then builds on the evaluation of and passing judgment on a direction of development.

The main attributes of our conception of sustainability science are (i) collaborative inquiry with a systems perspective to characterize complexity; (ii) diversity of theories and methods including the natural, social and practice-based sciences and humanities, that are juxtaposed in a process allowing for critical interdisciplinarity to transform each engaged discipline to overcome limiting and divergent assumptions and pre-suppositions (see also $\left[20^{\circ}\right]$ ); (iii) diversity of stakes and interest to understand and make explicit divergent preferences and priorities and their value bases that are united in their orientation to co-create more sustainable futures; (iv) requisites for processes to critique, judge and evaluate new knowledge emerging from such processes from diverse points of view; and (v) empathy, humility, reflection required when directing attention to people, roles and relationships in place-based and issue-based analysis.

This kind of transformative learning process assumes that knowledge is constructed for action, and that learning can be mediated by practice [21]. Transformative learning for sustainability, engages learners to rethink and act upon how societies and individuals interact with each other and their environments. Learning often happens by challenging boundaries of learning environments [22]. Learning is not only based on personal experience in the sense of Kolb [23], but learners - including teachers - need to be challenged by the experiences and perceptions of others in a dialectical manner. Transformative learning relies on collective learning in diverse groups, organizations or networks. In order to embrace complexity, conflict, uncertainty and ignorance we need to draw on plural rationalities and contradictory behavior. Successful learning interventions need to be managed to ensure that experiential situated knowledge from diverse communities of practice is made explicit, communicated and understood by others. In line with Sterling [24], transformative learning is considered as a life-long iterative process, doors to which may be opened through engagement in projects that integrate education, research and civic engagement [25].

Thus in the Certificate, contributors and participants are seen as members in a diverse learning community who engage with each other to shed light on multiple facets of complex problems, actively exchanging and learning from each other on a non-hierarchical social learning platform.

\section{What is the purpose of learning?}

The Certificate's overarching goal is to provide a better understanding of and repertoire of action on the complex challenges that societies, organizations and individuals face as we approach the limits of the biophysical carrying capacity of our planet. Sustainability and Social Innovation are inseparable: Active involvement of both citizens and science is necessary for guiding and monitoring the innovations that promise to protect or improve our lifestyles. The study programme offers tools for social learning to tap into the collective intelligence of stakeholders and experts. Issues such as energy, water and food production, waste and recycling, sustainable housing and transport are covered. The two core courses and auxiliary courses provide an overview on the most recent insights from academics and practitioners relating to global change and to transformational learning for sustainability. Peer group projects on complex transition problems in Luxembourg form another central aspect in the programme providing opportunities for engagement in collective problem-based scientific inquiry in small diverse groups with guidance from experts and stakeholders, to allow for transformative social learning. Such experiential learning opportunities equip participants for making better informed and, if diversity is managed successfully, also for making more reflexive judgments for effective action. The structure of the programme allows the design of an individual learning path (see Figure 1).

The Certificate offers a set of learning outcomes that can only be achieved based on direct experience of engaging and co-creating with a very diverse social learning group by combining theory and practice (see Box 2), 
Figure 1

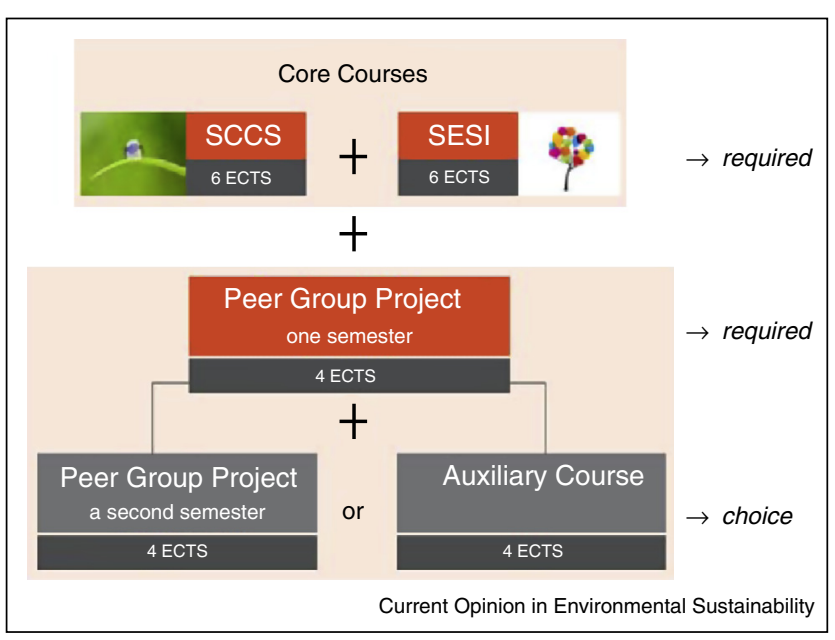

Options for personal learning paths. The Certificate requires 20 points of the European Credit Transfer System (ECTS) that can be collected by completing core courses, peer group projects and auxiliary courses. One ECTS point corresponds to a work load of about 1 hour, or a lecture of 45 minutes. Participation in the two core courses (6 ECTS each) and at least one semester of a peer group project (4 ECTS) is required. A second semester of a peer group project can be optionally replaced by completing an auxiliary course (4 ECTS). At the time of writing, two auxiliary courses were on 'Global Environmental Change in the Anthropocene (GECA) and on 'Sustainability Reporting' following the guidance of the Global Reporting Initiative (GRI). Individual learning paths can thus be more practice oriented by enrolling in two semester of peer group project (recommended), or home in more on the scientific knowledge base (GECA), or practical knowledge on developing organizational reports. The programme is designed to be compatible with a full-time job or study programme. Students have a choice: They can enroll to obtain the Certificate as second qualification in parallel to pursuing their main degree whilst at the University. Alternatively they can take individual courses as optional courses that count towards their main degree.

the experience of at least one semester of peer group work is considered essential.

\section{The content of the courses}

The Core Course 1 'Science and Citizens Meet Challenges of Sustainability' (SCCS) equips participants with conceptual tools and most recent insights from academics and practitioners to actively engage in societal transformation for sustainability in a networked world. Core Course 2 'Social Enterprise and Social Innovation' (SESI) explores social enterprises as vehicles for social innovation to address challenges of social inequity and sustainability. Sessions address a topic usually from diverse perspectives from the natural and social science and practice. All contributors are encouraged to state their assumptions in theory and methods they refer to as well as personal convictions and motivations to engage in their research or profession. These are requisites to allow for critical inter-disciplinarity, which directs attention to
Box 2 Main learning outcomes of the certificate in sustainability and social innovation

- To apply systems thinking to understand the complexity of society, environment and their interactions.

- To respect the conflicting perspectives on an issue that are held by diverse experts and stakeholders, stemming from diversity in experience, values and world views.

- To recognize uncertainties and tensions arising from the gulf between local and global perspectives and modes of inquiry.

- Skills in negotiation: respect, listening, giving and taking to find mutually acceptable solutions to complex problems.

- An appreciation of alternative forms of social organization and enterprise for achieving a sustainable economic exchange system.

- To develop 'citizen science' approaches and techniques for creatively integrating the social and scientific emphases of the two phases of the course.

- To engage science and scientists productively in social learning processes with diverse groups of stakeholders for concerted action on local issues of environment and sustainability.

limitations and contradictions between specific disciplinary approaches to generating new knowledge, explicit deliberation of resulting contradictions is however not always achieved.

'Complexity' is a central idea of all courses [26], uncertainty is present to all degrees, and there is no privileged perspective among participants. The role of measurement regimes and sets of indicators in defining, monitoring and tracking dynamics and defining progress and their role as devices for steering development across various levels of social organization is explored from diverse perspectives [27], including from sociology [28] and practice [29]. Building on [30] three different logics with which societal sustainability challenges may be tackled, and which often prove difficult to reconcile in social enterprises are discussed (community/reciprocity; hierarchy/redistribution; market/competition). In acknowledgement of the influence of learning environments we have organized course sessions in special co-working spaces that were recently set up to foster social and technological innovation in Luxembourg. ${ }^{2}$ Table 1 provides an overview on main content elements of the courses.

In terms of shaping course content with stakeholders and academics, the most difficult challenge has been to get a discussion on problems and trade-offs at the interface of the silos in which we usually organize our knowledge and governance systems, for example to systemically explore and anticipate future problems at the nexus of food-waterenergy systems. Furthermore, whilst the problem-based peer group projects have been organized with the goal of providing spaces for integration of perspectives from the

\footnotetext{
${ }^{2}$ For example, the $1535 \AA \mathrm{C}$ creativity hub Differdange: http://www. 1535.lu/; the Impactory: www.theimpactory.com.
} 
Table 1

\begin{tabular}{|c|c|c|}
\hline & What & Course \\
\hline Topics & Transformative sustainability science as social learning process & SESI \& SCCS \\
\hline \multirow{8}{*}{$\begin{array}{l}\text { (For each topic we stage discussion } \\
\text { of competing theories and practices) }\end{array}$} & $\begin{array}{l}\text { Competing conceptions of the economy, progress and the role } \\
\text { of social enterprise }\end{array}$ & $\begin{array}{l}\text { SESI } \\
\text { SESI }\end{array}$ \\
\hline & Equity as a dimension of sustainability & SCCS \\
\hline & Competing conceptions of science and progress & sccs \\
\hline & Cognition of complexity (challenges) & SESI \& SCCS \\
\hline & The role of measurement regimes as steering devices & SESI \& SCCS \\
\hline & Energy transition & SCCS \& GECA \\
\hline & Agricultural transition & SCCS \& GECA \\
\hline & Towards improved water governance & \\
\hline \multirow[t]{7}{*}{ Analytic conceptual tools } & Systems thinking (largely based on $[26,43])$ & SESI \& SCCS \\
\hline & The Multi Level Perspective on Socio-Technical Transitions & SESI \\
\hline & (largely based on [44]) & SESI \\
\hline & Competing logics in the social and solidarity economy [30] & SCCS \& GECA \\
\hline & The business canvas model [45] & SCCS \& GECA \\
\hline & Scenario analysis collaboration with Oxford Scenarios & SCCS \& GECA \\
\hline & $\begin{array}{l}\text { Uncertainty characterization (see www.nusap.net for } \\
\text { resources) }\end{array}$ & \\
\hline \multirow[t]{6}{*}{ Methods } & Methods for tapping into collective intelligence in workshops [48] & SESI \& SCCS \\
\hline & Co-Design Processes [49] & SESI \\
\hline & Presencing techniques [50] & SESI \\
\hline & Multi-criteria analysis [42] & sccs \\
\hline & Citizen science $\left[10^{\circ}\right]$ & sccs \\
\hline & Sustainability Reporting in Organizations (largely following the & GRI \\
\hline
\end{tabular}

natural and social sciences from the courses this has not always been achieved.

\section{How is transformative problem-based learning organized?}

This conception of transformative learning is to that of Wals who describes it as 'opening up to and relating in a different manner to diverse ways of knowing, based on interacting with others and the world around you' [31,32]. Thus, the emphasis in the design of peer group projects is on creating spaces to work with contradicting perspectives and framings from theory and practice and dealing with resulting controversies on how best to create actionable knowledge. The projects stage collective scientific inquiry relying on cycles of action and reflection. Diverse learning environments and situated scientific inquiry including interviews and observational studies have proven essential. They enable the linking of identity, community, and place and consider citizen science as a tool for reconnection to concrete situated problems and local stakes and interests [12,33 ${ }^{\bullet}$.

Peer groups were encouraged to draw on methods to draw systematically on collective intelligence (see Table 1. Section on 'Methods'). The projects were cocreated together with academics and stakeholders who are active in transition practice in the public sector, private sector or organised civil society in Luxembourg and some of whom provide guidance to the projects. (See overview on peer group projects Table 2.) Participants in each group were selected based on their motivation and diversity within the groups with respect to age and expertise/disciplinary backgrounds.

Peer group projects are participant-led in that the group remit initially has a broad scope, and the group has to develop their own problem-framing and specific approach. For example, peer groups on democratizing renewable energy first had to agree on an angle of interest to all group members, for example how the group may develop resources of interest for establishment of citizen cooperatives in the energy sector. The groups are asked to draw together more abstract academic literature resources on social innovation and the structure of the energy sector, legal and regulatory documents, as well as practical information on local emerging citizen cooperatives, specific local problems, and information from direct interaction and guidance on needs by active members of three energy cooperatives in Luxembourg.

The main challenge encountered in organizing peer group projects is the resource intensity of guiding groups to establish a social learning process with stakeholders on complex problems. First, time-wise, one semester projects proved just sufficient for most groups to develop a 


\begin{tabular}{|c|c|c|c|}
\hline \multicolumn{4}{|l|}{ Overview on peer group projects } \\
\hline Peer group topics & Participants/semesters & Stakeholder interaction & Final reports \\
\hline $\begin{array}{l}\text { Democratizing renewable energy (often } \\
\text { focused on building energy cooperatives) }\end{array}$ & $35 / 6$ & Meetings, interviews, 1 workshop & 4 \\
\hline $\begin{array}{l}\text { New forms for cooperative and social } \\
\text { housing schemes }\end{array}$ & $8 / 2$ & Meetings, interviews & 2 \\
\hline $\begin{array}{l}\text { Socio-technical transition in } \\
\text { municipalities - the role of local indicators }\end{array}$ & $33 / 6$ & $\begin{array}{l}\text { Meetings, interviews, Survey, } \\
\text { focus groups, } 2 \text { workshops }\end{array}$ & 4 \\
\hline $\begin{array}{l}\text { Promoting waste reduction, reuse, and } \\
\text { recycling on and beyond campus }\end{array}$ & $17 / 4$ & Meetings, interviews & 4 \\
\hline Water Governance & $11 / 2$ & Meetings, interviews, 2 surveys & 2 \\
\hline
\end{tabular}

common framing and understanding of the complexity of the issue at stake and come to terms with differences in values and view points in the group and have tensions surface, but insufficient to a group reflective process in this setting. Usually there was insufficient time to overcome tensions productively. Reports after one semester often just mapped the issues, but provided little link to theory discussed in class and conceptual analysis. Some more successful groups demonstrated significant achievements in particular where mentors facilitated the social group process to understand differences and find common ground in the beginning. Since the year 2014/2015 peer groups now run for one year instead of just one semester. Teaching modules on systematic documentary research and project management are being added. Non-academic experts and mentors are invited to the Core courses to guide the groups to draw on relevant theory and methods. The challenge of resource intensity of providing guidance for transformative learning opportunities remains another key area of improvement. An innovative evaluation approach has been implemented in an attempt to manage diversity and tensions in groups and to deploy resources offering guidance more effectively.

\section{Evaluation and judgment}

Evaluation of such transformative learning should thus serve purposes of informing further learning and accountability [34]. Four overlapping objectives of evaluation in the Certificate are described in Figure 2. For evaluation to effect learning, each individual participant is encouraged to keep a reflective diary, and in the self-assessment has to reflect on their own level of engagement and learning at

\section{Figure 2}

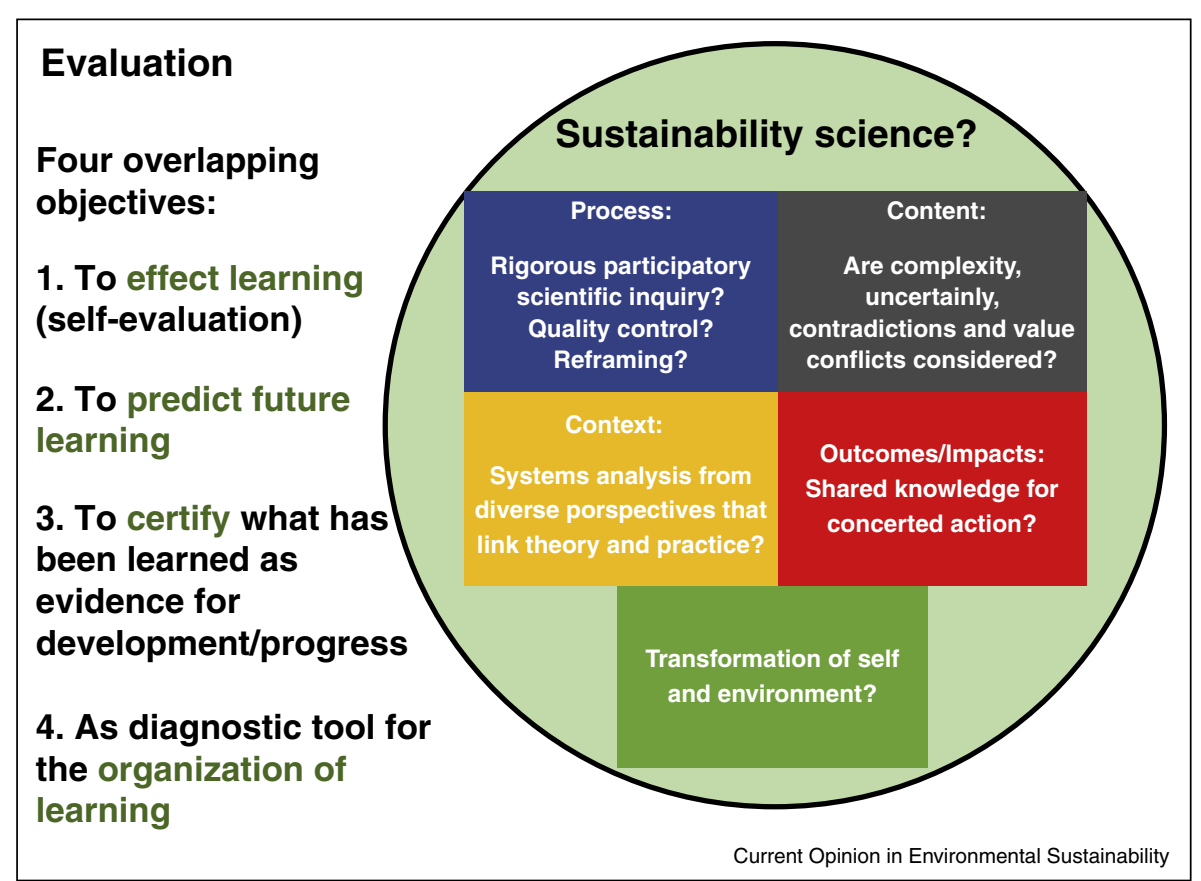

Evaluation has four objectives, shown as numbered list on the left of the figure, and addresses five dimensions of sustainability science represented as boxes in the circle. Overarching questions for evaluation of each dimension are listed each box. 
the end of each semester. A final synthesis report asks for one section (which is not considered in grading) with reflection on impacts of the course on personal and professional plans. About two thirds of the reports provide evidence of individual transformative learning, as suggested by the two extracted statements below (see Box 3). In 2015 an evaluation based on survey questionnaires was added.

The evaluation of peer group projects relies on judgments at several levels: Self-evaluation by participants; peer group self-assessment in a group discussion; and evaluative feedback by the 'peer project steering group', that is, the facilitators, together with key stakeholders in the project. Evaluation through multiple perspectives is deemed more valuable for learning than just drawing on one perspective. First, at the end of each semester a 360 degree feedback is organized, where each participant is asked to evaluate their level of engagement and that of all other members in the group. The peer group then reflects on their work, pooling individual reflections in a group judgment of strengths and weaknesses of their work. These reflections are included in the peer group presentation and in the final written report, These in turn are evaluated by group facilitators and the course coordinator.

The external stakeholders' part of the evaluation through the project steering group is essential for a social learning platform. They include key actors in the Luxembourg transition and social innovation movements, such as a business angel who also the chair the board of the European Venture Philanthropy Association, the founder of Luxembourg's largest renewable energy cooperative, and the co-founders of Luxembourg's rapidly growing transition movement, as well as officials from the Ministry for Sustainable Development and STATEC and EUROSTAT (Table 3).
Box 3 Quotes from participants and contributors in evidence of perspective changes and transformative learning

'This course improved my critical thinking enormously.' Student BA Economics

'It was a great experiencing such diverse perspectives striving towards a common goal during the course. This changed my idea of sustainability, which I now conceive like a puzzle where you need a lot of different pieces to get a better picture of a complex situation.' Ph.D. candidate, Environmental Psychology

'Scientists, professionals and researchers of various backgrounds meet and discuss with motivated students and other participants about the essential challenges current society has to face if it wants to stay afloat. For once the real questions are addressed - openly, directly, without ado or make-up. It has features of a social psychoanalysis, digging into the depth of the problems of today's society and sometimes painfully carving out the causes. SCCS [...] is not the ivory tower, it is an actual laboratory for real-time research on today's society and its challenges ... to be continued!' Director, Luxembourg State Savings Bank et Conseiller d'Etat.

The project steering group is composed of all peer group project facilitators in any given academic year, and of other stakeholders in the Certificate who are interested in past, present or future peer group projects. The steering group meets and evaluates these and develops feedback as a team. On this basis work for the next semester is planned. The 'peer project steering group' also provides feedback on the study programme and outcomes in more general terms, from their perspective on how well the programme manages to develop an interface with transition initiatives in Luxembourg and how policy makers and entrepreneurs are trying to foster systemic change for sustainability. All feedback is considered in the design of the next year's programme, including course work and peer group projects. Selected quotes on the transformative impacts of the study programme from participants and a contributor are presented in Box 3 .

\begin{tabular}{|c|c|c|}
\hline \multicolumn{3}{|c|}{ Multi-level evaluation and feedback approach } \\
\hline & Participants & Contributors/Stakeholders \\
\hline Courses & $\begin{array}{l}\text {-Evaluation and self-evaluation of personal learning } \\
\text { in the part II individual reports (no marks on this) } \\
\text {-Over } 80 \text { reflective reports on courses in five years } \\
\text {-Web-based questionnaire } \\
\text {-Focus group evaluation in closing session }\end{array}$ & $\begin{array}{l}\text {-Focused group discussion and feedback } \\
\text { collection in course planning meetings each } \\
\text { semester - documented } \\
\text {-Interaction with individuals on issues of concern }\end{array}$ \\
\hline Peer group projects & $\begin{array}{l}\text {-21 projects over four years } \\
\text { peer group interim reports } \\
\text {-Conduct of an expert panel evaluation of final } \\
\text { project presentations (academics and stakeholders) } \\
-12 \text { formal reports since the official start of Certificate } \\
\text {-Self-evaluation of engagement and learning and } \\
\text { evaluation as part of } 360 \text { feedback at end of each } \\
\text { semester over two years } \\
\text {-Group evaluation of project as part of final } \\
\text { presentation and report }\end{array}$ & $\begin{array}{l}\text {-Focused group discussion and feedback } \\
\text { collection in peer group planning meetings each } \\
\text { semester - documented } \\
\text {-Interaction with individuals on issues of concern } \\
\text { - Over four years we held } 7 \text { focus group meetings of } \\
\text { contributors to discuss merits limitations } \\
\text { improvements at the end of each semester }\end{array}$ \\
\hline
\end{tabular}


These quotes present evidence of transformative learning at all levels. Individual level participant's statements B.A. and Ph.D. and a contributor who also highlights benefits from participation in this platform to gain new perspectives. At the level of the programme organisation, the Certificate has benefitted and changed progressively in consecutive years, and we actually although aiming for relational change come closer to organizing the course around competences often stated as learning outcomes in sustainability education [35].

However, impact and outcomes remain ill-defined and difficult to report on. Societal effects for systemic change will be similar to those described for participatory sustainability research $\left[36^{\circ \bullet}\right.$ ], including the whole range of quality products, knowledge gains, increased decisionmaking capacity, enhanced networks and transformational changes. In further development of the evaluation approach more time will need to be invested on defining what is to be evaluated and how in particular as regards the contribution to systemic change.

\section{Areas for improvement and outlook}

The Certificate experiments with a novel approach for combining within a study programme the practice of transformative social learning with scientific inquiry in diverse groups of engaged students, professionals and academics, similar to conceptions of the new role of the University in the face of sustainability challenges advanced by Sterling [37] and Barth [15 ${ }^{\circ}$ ], p. 166. The Certificate intends to provide a space for social learning engaging scientific inquiry, to complement activities driven by organized civil society or government to foster systemic change for sustainability. The emphasis in the Certificate is placed on drawing on critical research and on improved ways to capture and jointly evaluate outcomes and impacts from diverse perspectives.

The approach relies on careful building of a network of diverse participants and management of this diversity to gain a shared understanding of very diverse facets of complex sustainability issues in a pluralist society. It also matters that learning experiences are embedded in diverse learning environments, including formal, informal, non-formal educational settings. Programme design should direct attention to the complementarity of physical, institutional and virtual learning environments $\left[8,33^{\bullet}, 38\right]$.

The areas for improvement identified in this paper may however also point to the limits of a mere study programme to contribute to systemic change. This paper has pin-pointed four main areas for improvement. The first issue is to find improved ways to give a programme with international perspectives and contributions traction in local settings on local issues; in view of challenges of extrapolation of global abstract insights exasperated by challenges of working in a multi-lingual and multi-cultural setting is a key area for future improvements. The second challenge relates to overcoming knowledge and governance silos more effectively to allow for more targetted social innovation, for example to jointly explore problems and anticipate future problems at the nexus of food-water-energy systems. Improved conceptual and methodological approaches are required to integrate knowledge from diverse disciplines and practice, as well as problem-solving with critical perspectives.

Third the resource intensity of organizing transformative learning opportunities in the form of peer group work is notable, in particular if these are set up in isolation from research projects. This has led to a critique of a risk of developing an elitist study programme that is not in reach with resources available at a typical main stream large scale university as in Germany or France. Finally, further formalizing qualitative and quantitative evaluation depends on improved definitions of potential outcomes and impacts. To date, iterative joint critique and evaluation of this programme has proven essential for fostering the programme's potential to contribute to systemic change by producing salient knowledge for transition initiatives in. There is however further room for improvement of this.

More formal institutional spaces for transformative sustainability science projects on salient and existential issues with key stakeholders are required, formalization is expected to stabilize these as learning environments. Approaches such as those described by Evans et al. [39] and Rosenberg et al. [40] in this volume seem complementary to the approach of building a dedicated study programme to build capacity for engaging scientists and citizens in sustainability science. Possible forms for such institutional spaces can include multi-year research projects. The time-factor should not be under-estimated, experience suggests groups require time and a safe and guided learning process to open up to being criticized in a constructive manner, this is why formalized institutional spaces are required to provide more stability for social interactions amongst diverse stakeholders and social learning over time. Capacity building amongst stakeholders for the deployment of emergent methods to tap into collective intelligence will be required. New quality criteria and quality control mechanisms are required for knowledge co-creation processes with diverse stakeholders $[41,42]$.

In sum, this study programme describes an innovative approach to building and situating the Universities as a nodal point in a social learning in network of stakeholders in place-based and issue-based sustainability transitions in Luxembourg. This paper suggests that a research platform for transformative sustainability science that builds several issue-based sustainability science projects, 
will help to stabilize network building for social learning to occur over time. Such research projects will provide a demand for and an opportunity to better leverage what the study programme has to offer in terms of equipping scientists and citizens for engagement in sustainability science for systemic change in Luxembourg and beyond.

\section{Acknowledgements}

No single mind could have created this study programme. Without the high level of engagement of colleagues at the university from all faculties, the Luxembourg Institute for Science and Technology, the Ministry for Sustainable Development and Infrastructures of Luxembourg, STATEC, EUROSTAT, the European Investment Fund, and numerous other organizations, and all participants this programme could not have been built. Dr Jerome Ravetz provided intellectual and moral support and continued substantial inputs through-out the building of the programme. The programme's development and implementation was funded by the University of Luxembourg.

\section{References and recommended reading}

Papers of particular interest, published within the period of review, have been highlighted as:

- of special interest

$\bullet$ of outstanding interest

1. Kuhn TS: The Structure of Scientific Revolutions. 3rd ed.. Chicago: The University of Chicago Press; 1962.

2. Jerneck A, Olsson L, Ness B, Anderberg S, Baier M, Clark E, Hickler T, Hornborg A, Kronsell A, Lövbrand E, Persson J: Structuring sustainability science. Sustain Sci 2011, 6:69-82 http://dx.doi.org/10.1007/s11625-010-0117-x.

3. Feyerabend PK: Three dialogues on knowledge. Oxford: Blackwell; 1991.

4. Funtowicz S, Ravetz JR: Science for the post-normal age. Futures 1993, 25:739-755 0016-3287/93/07739-17.

5. Nowotny H, Scott P, Gibbons M: Re-Thinking Science Knowledge and the Public in an age of Uncertainty. Polity Press; 2001.

6. Kates RW, Clark WC, Corell R, Hall JM, Jaeger CC, Lowe I, McCarthy JJ, Schellnhuber HJ, Bert Bolin, Dickson NM et al.: Sustainability science. Science 2001, 292(4):641-642 http:// dx.doi.org/10.1126/science.1059386 Retrieved from www. sciencemar.org.

7. Miller TR, Wiek A, Sarewitz D, Robinson J, Olsson L, Kriebel D, Loorbach $\mathrm{D}$ : The future of sustainability science: a solutionsoriented research agenda. Sustain Sci 2013, 9:239-246 http:// dx.doi.org/10.1007/s11625-013-0224-6.

8. König A: Regenerative Sustainable Development of Universities and Cities. Edward Elgar; 2013.

9. Schneidewind U, Singer-Brodowski M: Transformative Wissenschaft: Klimawandel im deutschen Wissenschafts- und Hochschulsystem. Metropolis, Marburg; 2014:: 419:. http://www. nachhaltigewissenschaft.blog.de.

10. Wals AEJ, Brody M, Dillon J, Stevenson RB: Convergence

- between science and environmental education. Science 2014 344:583-584

A compelling call for embracing citizen science projects to oster social learning on environmental issues.

11. Wiek A, Lang DJ: Transformational sustainability research methodology. In Sustainability Science - An Introduction. Edited by Heinrichs H, Martens P, Michelsen G. Springer; 2015:112.

12. Peters $S$, Wals $A E J$ : Learning and knowing in pursuit of sustainability: concepts and tools for trans-disciplinary environmental research. In Trading Zones in Environmental Education: Creating Transdisciplinary Dialogue. Edited by Krasny M, Dillon J. Peter Lang; 2013:79-104.
13. Jasanoff S: Technologies of humility: citizen participation in -• governing science. Minerva 2003, 41:223-244 http://dx.doi.org/ 10.1023/A:1025557512320.

This paper presents a set of questions that can be considered as essence for sense-making in diverse groups about decisions and associated trade-offs for jointly defining and striving for progress. Whilst it has been written already over ten years ago, I have yet to encounter another paper of comparable value in structuring activities and organizing and facilitating discussions with stakeholders.

14. Jasanoff S: Ordering knowledge, ordering society. In States of Knowledge: The Coproduction of Science and Social Order. Edited by Jasanoff S. Routledge; 2004:13-46.

15. Barth M: Towards Systemic Social Learning In Implementing

- Sustainability in Higher Education: Learning in an Age of Transformation. Learning in an Age of Transformation (Earthscan). Routledge; 2015.

The book explores the role of universities in fostering systemic social learning for transformative change. It provides a comprehensive overview on approaches, barriers and challenges as well as strategies on how to overcome these.

16. Keen M, Brown VA, Dyball R (Eds): Social learning in Environmental management: Towards a sustainable future, Earthscan; 2005.

17. Steyart $P$, Jiggins J: Governance of complex environmental situations through social learning: a synthesis of SLIM's lessons for research, policy and practice. Environ Sci Policy 2007, 10:575-586

18. Dewey J: Experience and education.. Touchstone (Simon \& Schuster 1997 (C)1938); 1938:: 91.

19. Jaeggi R: Kritik von Lebensformen. Suhrkamp; 2011.

20. Boix-Mansilla V: Learning to synthesize: the development of

- interdisciplinary understanding. In The Oxford Handbook of Interdisciplinarity. Edited by Frodeman R, Thompson Klein J, Mitcham C. Oxford University Press; 2010:288-309.

This book chapter presents a pragmatic framework for achieving critical crosstalk between scientists active in disparate disciplinary fields.

21. Lotz-Sisitka H, Raven G: Learning through cases: adopting a nested approach to case-study work in the Gold-Fields participatory course initiative. Environ Educ Res 2004, 10:67-87.

22. Seely Brown J, Collins A, Duguid P: Situated cognition and the culture of learning. Educ Res 1989, 18(1):32-42.

23. Kolb DA: Experiential Learning: Experience as the Source of Learning and Development. Prentice Hall; 1983.

24. Sterling S: Higher Education, sustainability and the role of systemic learning. In Higher Education and the Challenge of Sustainability: Problematics, Promise and Practice. Edited by Corcoran PB, Wals AEJ. Kluwer Academic Publishers; 2004:4770.

25. Gough S, Scott W: Higher Education and Sustainable Development: Paradox and Possibility. Routledge; 2007.

26. Vester F: The Art of Interconnected Thinking. MCB Publishing House; 2012.

27. Reed MS, Fraser EDG, Dougill AJ: An adaptive learning process for developing and applying sustainability indicators with local communities. Ecol Econ 2006, 59:406-418 http://dx.doi.org/ 10.1016/j.ecolecon.2005.11.008.

28. Manhart S: Kalkulierte Krise. Zählen, Rechnen und Messen als Grundlagen der Moderne Arch+ Zeitschrift für Architektur und Städtebau. 2012:17-21.

29. Radermacher W: The reduction of complexity by means of indicators - case studies in the environmental domain. In Statistics, Knowledge and Policy: Key Indicators to Inform Decision Making. Edited by OECD. 2005:163-173. http:// www.sourceoecd.org/general/economics/9264009000.

30. Defourny J, Nyssens M: The EMES approach of social enterprise in a comparative perspective (No. WP no. 12/03) ( $p$. 28). Liège, 2012.

31. Wals AEJ, Heymann FV: Learning on the edge: exploring the change potential of conflict in social learning for 
sustainable living. In Educating for a Culture of Social and Ecological Peace. Edited by Wenden A. State University of New York Press; 2004:123-145.

32. Wals AE, Blewitt J: Third-wave sustainability in higher education: some (inter)national trends and developments. In Sustainability Education: Perspectives and Practice Across Higher Education. Edited by Jones P, Selby D, Sterling S. Earthscan; 2010:55-75.

33. Medema W, Wals A, Adamowski J: Multi-loop social learning for - sustainable land and water governance: towards a research agenda on the potential of virtual learning platforms. NJAS Wageningen J Life Sci 2014, 69:23-38 http://dx.doi.org/10.1016/ j.njas.2014.03.003.

A compelling paper describing merits and limitations of virtual spaces associated with citizens science projects as scalable platforms for social learning.

34. Guba L: Fourth Generation Evaluation. Sage; 1989.

35. Wiek A, Withycombe L, Redman CL: Key competencies in sustainability: a reference framework for cademic program development. Sustain Sci 2011, 6:203-218 http://dx.doi.org/ 10.1007/s11625-011-0132-6.

36. Wiek A, Talwar S, O'Shea M, Robinson J: Toward a

-. methodological scheme for capturing societal effects of participatory sustainability research. Res Eval 2014, 23:117132.

This paper develops a framework and ethodological scheme for capturing societal effects of participatory sustainability research.

37. Sterling S: The sustainable university: challenge and response. In The Sustainable University. Progress and Prospects. Edited by Sterling S, Maxey L, Luna H. Taylor \& Francis Group; 2014:17-50.

38. Ryan A, Cotton D: Times of change: shifting pedagogy and curricula for future sustainability. In The Sustainable University. Progress and Prospects. Edited by Sterling H, Maxey S, Luna L. Routledge; 2014:151-167.

39. Evans J, Jones R, Karvonen A, Millard L, Wendler J: Living labs and co-production: University campuses as platforms for sustainability science. Curr Opin Environ Sustain 2015, 16:1-6.
40. Rosenberg D, Trencher G, Petersen J: Students as change agents in a town-wide sustainability transformation: the Oberlin Project at Oberlin College. Curr Opin Environ Sustain 2015, 16:14-21.

41. Funtowicz SO, Ravetz JR: Peer review and quality control. In International Encyclopedia of the Social \& Behavioral Sciences, Vol 17. Edited by Wright JD. Oxford: Elsevier; 2015:690-694.

42. Stirling A: A general framework for analysing diversity in science, technology and society. J R Soc Interface/R Soc 2007 4:707-719 http://dx.doi.org/10.1098/rsif.2007.0213.

43. Ravetz JR: Post-Normal Science and the complexity of transitions towards sustainability. Ecol Complexity 2006, 3:275284 http://dx.doi.org/10.1016/j.ecocom.2007.02.001.

44. Geels FW, Schot J: Typology of sociotechnical transition pathways. Res Policy 2007, 36:399-417 http://dx.doi.org/ 10.1016/j.respol.2007.01.003.

45. Osterwalder A, Pigneur Y: Business Model Generation: A Handbook for Visionaries, Game Changers and Challengers. John Wiley and Sons; 2010:: 288.

46. Stringer Swart R, Raskin $P$, Robinson J: The problem of the future: sustainability science and scenario analysis. Global Environ Change 2004, 14:137-146 http://dx.doi.org/10.1016/ j.gloenvcha.2003.10.002.

47. Elahi S: Here be dragons... exploring the "unknown unknowns." Futures 2011, 43:196-201 http://dx.doi.org/10.1016/ j.futures.2010.10.008.

48. Muff K: The Collaboratory: A Co-creative Stakeholder Engagement Process for Solving Complex Problems. Greenleaf Publishing; 2014:: 300 .

49. Brown T: Design thinking. Harvard Business Rev 2008, 86:84-92 141. Retrieved from http://www.ncbi.nlm.nih.gov/pubmed/ 18605031.

50. Senge P, Scharmer CO, Jaworski J, Flowers BS: Presence: Human Purpose and the Field of the Future. Crown Business, Random House; 2004. 